\title{
LESSER ADJUTANT LEPTOPTILOS JAVANICUS HORSFIELD, 1821 (CICONIIFORMES: CICONIIDAE) IN THE DRY LOWLANDS OF SRI LANKA: DISTRIBUTION, ECOLOGY, AND THREATS
}

\author{
Thilina N. de Silva ${ }^{1}$, Sumudu Fernando ${ }^{2}$, Haritha B. de Silva ${ }^{3} \&$ Parami Tennakoon ${ }^{4}$ \\ ${ }^{1,2}$ Biodiversity Institute, University of Kansas, 1345 Jayhawk Blvd, Lawrence, KS 66045, USA \\ ${ }^{3}$ Defenders of Wildlife Sri Lanka, PO Box: 42/11, Pragathi Mawatha, Uda Eriyagama, Peradeniya 20400, Sri Lanka \\ ${ }^{4}$ Assistant Divisional Secretary, Divisional Secretariat, Dimbulagala 51031, Sri Lanka \\ thilina@ku.edu (corresponding author), 2sumudu27@gmail.com, ${ }^{3}$ haritha1102@gmail.com, \\ ${ }^{4}$ parami1984@yahoo.com
}

\begin{abstract}
The Lesser Adjutant Leptoptilos javanicus is a globally threatened species of stork; in Sri Lanka, it is a scarce resident breeder, and the largest bird in the country, yet the population status and ecology of the species is poorly understood. This study tracks the stork's spatial distribution and habitat use within the island, along with aspects of its ecology. Data was collected via field sampling and questionnaire surveys, over a period of five years across the lowlands of the country. The bird was observed 184 times, with numbers per sighting ranging from 1-17 individuals. The species' distribution was restricted to dry lowlands (rainfall $<2200 \mathrm{~mm}$, elevation $<300 \mathrm{~m}$ ). The bird showed preference for savannah/woody savannahs, dry mixed evergreen forests, permanent wetlands, and croplands, and was prominently found within protected areas. Lesser Adjutants were generally solitary, except in the driest months of the year (i.e., AugustSeptember and March-April), which are probably the two breeding periods of the bird in Sri Lanka. Except for an abandoned nest, no active nest was found. Habitat loss and fragmentation, hunting pressure, agricultural intensification, and development projects were identified as potential threats faced by the species, which varied in magnitude across the country.
\end{abstract}

Keywords: Conservation, local stakeholder communities, protected areas, random distribution value, species range, stork-nesting behavior, threatened species, wildlife questionnaire surveys.
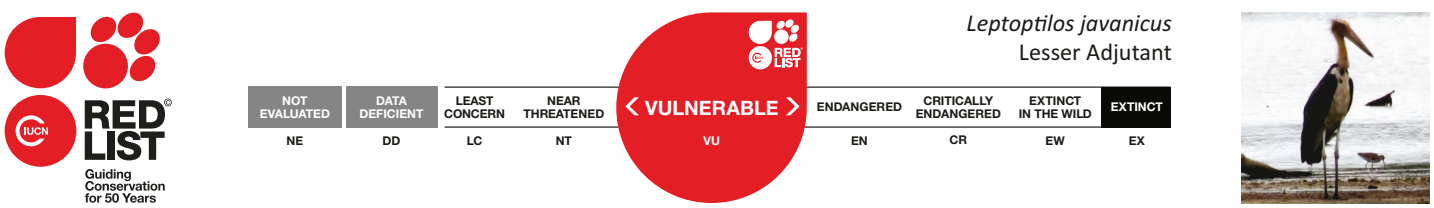

DOI: http://dx.doi.org/10.11609/jott.2425.7.14.8089-8095 | ZooBank: urn:Isid:zoobank.org:pub:B265683E-73A8-404A-B273-3ECC584BAF61

Editor: K.S. Gopi Sundar, International Crane Foundation, Baraboo, USA.

Date of publication: 26 November 2015 (online \& print)

Manuscript details: Ms \# 04174 | Received 15 October 2014 | Final received 18 October 2015 | Finally accepted 06 November 2015

Citation: de Silva, T.N., S. Fernando, H.B. de Silva \& P. Tennakoon (2015). Lesser Adjutant Leptoptilos javanicus Horsfield, 1821 (Ciconiiformes: Ciconiidae) in the dry lowlands of Sri Lanka: distribution, ecology, and threats. Journal of Threatened Taxa 7(14): 8089-8095; http://dx.doi.org/10.11609/jott.2425.7.14.8089-8095

Copyright: (c) de Silva et al. 2015. Creative Commons Attribution 4.0 International License. JoTT allows unrestricted use of this article in any medium, reproduction and distribution by providing adequate credit to the authors and the source of publication.

Funding: self-funded (by our organization Defenders of Wildlife Sri Lanka).

Conflict of Interest: The authors declare no competing interests.

For Author Contribution and Author Details see end of this article.

Acknowledgements: We acknowledge Dr. A. Townsend Peterson for his help in improving the paper. We would also like to thank Nuwanthika Perera and Chathurika Munasinghe for providing us photos of the target species.
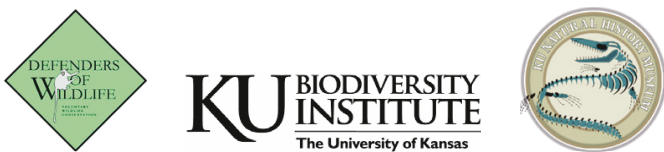


\section{INTRODUCTION}

The Lesser Adjutant Leptoptilosjavanicus is the smallest of the three species of storks in the genus Leptoptilos; it is nonetheless a very large stork $(122-129 \mathrm{~cm})$ with a heavy yellowish bill, bare head and neck with no pendant pouch, ashy-greenish-black above, and dirty white below (Henry 1998; BirdLife International 2013). While this stork is distributed broadly across South and South-East Asia, its range is highly discontinuous, with sizable populations occurring mainly in Cambodia (1,500-3,500 pairs), India (1,200 mature individuals), Malaysia (300 individuals), Nepal (200-700 individuals) and Indonesia (c.2,000 in 1993 but in decline). Smaller breeding populations exist in Sri Lanka, Bangladesh, Myanmar, Laos, Bhutan, Brunei, Vietnam, and Thailand; however the species is apparently extinct in China and Singapore (BirdLife International 2013). The global population is estimated at 6,500 to 8,000 mature individuals (Chowdhury \& Sourav 2012) with numbers declining due to anthropogenic activities with varying effects across its range. As a consequence the stork is currently listed as Vulnerable (BirdLife International 2013).

In Sri Lanka, the Lesser Adjutant is the country's largest bird, although it is not as tall as the Black-necked Stork Ephippiorhynchus asiaticus. It is uncommon, preferring undisturbed wilderness, and frequenting the loneliest of water holes, jungle tanks, and dry riverbeds in the dry lowlands of Sri Lanka (Henry 1998; Harrison \& Worfolk 1999). Subaraj \& Lok (2009) indicate that a hundred pairs of Lesser Adjutant have been recorded from Sri Lanka. At present, however, it is listed as nationally threatened and vulnerable (MOE 2012). Interestingly, no recent nesting records exist from Sri Lanka, though it is certain to breed on the island (Henry 1998).

In this paper we present preliminary findings on the ecology, habitat use, and distribution of the bird as well as potential threats faced in Sri Lanka, which will be invaluable to formulating informed conservation strategies to ensure long-term survival of the species. The paper lays a foundation on which detailed future scientific work can be carried out on aspects of the species' ecology, habitat usage, and population status.

\section{MATERIALS AND METHODS}

A thorough literature survey outlined the state of knowledge of the potential habitat and possible range of the species within Sri Lanka. Fieldwork was carried out from January 2008 to August 2013. Point-counts, road-based counts, and arbitrary field visits were done throughout the period of study, covering most of the bird's historical range, to collect data on species distributional patterns and habitat use, as well as feeding and nesting behavior (Images $1 \& 2$ ). Nest searches were done throughout the study period with the help of local villagers and park rangers. The study covered much of Sri Lanka's dry lowlands, except for the northern districts of Jaffna, Killinochchi, Mulaitivu, and Vavuniya (due to inaccessibility). The Mannar District and some parts of the Eastern Province were sampled in 2010 and later. At every sighting of the species, numbers of individuals were recorded, and the geographic coordinates of the location were obtained via Google Earth.

In addition, geographic data sets of protected areas, inland water and elevation for Sri Lanka were obtained from DIVA-GIS (2014). Climate preferences of the species were studied by mapping the geographic coordinates of observations on annual rainfall maps using ArcGIS 10.1 (ESRI 2011). The overall distribution pattern and the monthly variation of the species were analyzed. Occurrence of the bird inside and outside of protected areas, and the presence of the species in relation to rainfall-ranges were analyzed. A one-kilometer buffer around major water bodies allowed us to examine the effect of wetlands on the distribution of the species in each month.

Random distribution values $(D)$ were obtained for protected areas and rainfall-ranges by multiplying the total observed individuals during the study $(n)$ by percentage expanse of each zone of consideration, assuming species were randomly distributed across all landscapes.

Observed results were compared against random distribution values to assess if the species preferred certain rainfall ranges, and protected areas, over pure chance. Since areas were not equally represented in all rainfall ranges or protected/ unprotected areas, this method was useful to determine if the species showed specific preferences.

A questionnaire was distributed among selected local communities involved in professions such as fisheries, agriculture, wildlife management, hunting, defense, and primary/secondary education. The main objectives were to discover nesting sites, to understand actual threats faced by the species from region to region, to educate conservation priorities and to gain an insight into the local knowledge on the species' ecology. Along with the questionnaire, a pictorial album of storks in Sri Lanka was used to help people identify the bird correctly. 


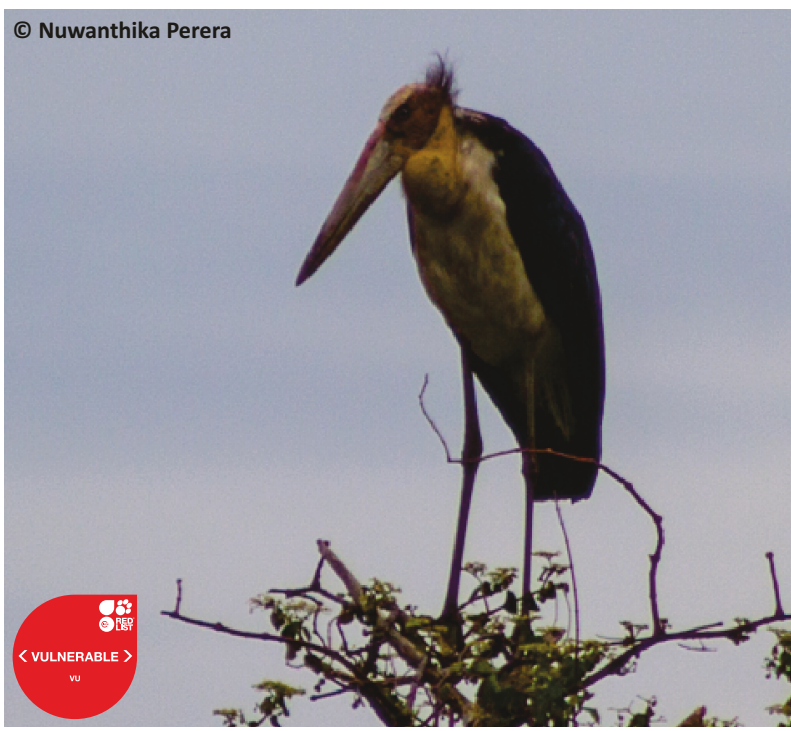

Image 1. Lesser Adjutant resting on the tree canopy with head sunk into the shoulders, Wilpattu National Park, Sri Lanka

\section{RESULTS}

The Lesser Adjutant was present throughout the dry lowlands of Sri Lanka, with observations from the northwestern, north central, eastern, Uva, and southern regions (Fig. 1). The bird was not observed in wet regions (annual rainfall above 2,200mm); indeed, the species was often found in the driest lowland areas (elevation < $300 \mathrm{~m}$ ) of the island (Fig. 2). During the study, Leptoptilos javanicus was observed on 184 occasions. Though the number of birds observed in a single sighting ranged from 1-17 individuals, most sightings were of solitary individuals (Fig. 3). The mean size of assemblages (the term "assemblage" is used here over "flock" referring to a non-interactive collection of individuals of the same species observed in a given location, due to the nonflocking nature of the focal species) was higher in March, April, and September; whereas solitary individuals were most commonly seen during the rest of the year (Fig. 4).

Field notes on habitat use indicated that the bird was regularly found on Savannah/woody savannahs, dry mixed evergreen forests, permanent wetlands, and croplands (Table 1). The mean assemblage size was comparatively higher when the species was recorded from the permanent wetlands, than from other habitat types where the bird was often observed solitarily.

During most parts of the year, most sightings were from within protected areas in the low country (Fig. 5). The observations were also concentrated within the water buffer zone (Fig. 6) despite its relatively small expanse ( $23 \%$ of total land area).

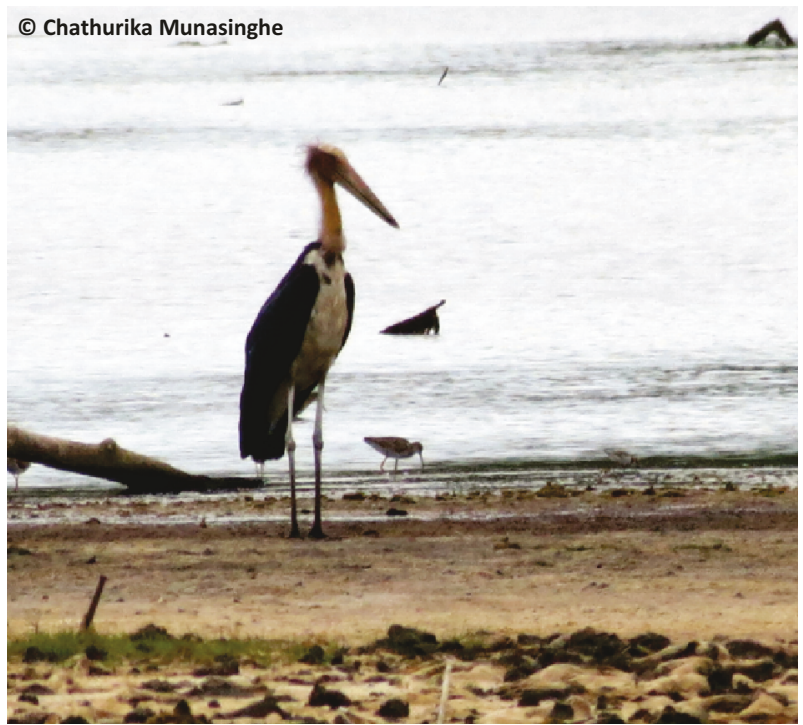

Image 2. Lesser Adjutant on the look out for prey, Wasgomuwa National Park, Sri Lanka.

In all, 18 observations were of foraging birds. Food sources included fishes (Periopthalmus Mudskippers, Mystus catfishes, Oreochromis spp., Channa spp., cyprinid fishes, Anguila eels.), snakes (Xenochrophis asperrimus, Ptyas mucosa), small to medium-sized lizards, bullfrogs, insects (grasshoppers in particular), and crabs. An assemblage of 14-17 individuals of Lesser Adjutants was observed foraging in a drying pool in Paankulam, in late morning on September 2012. They accompanied Black-headed Ibises (Threskiornis melanocephalus), Painted Storks (Mycteria leucocephala), Spot-billed Pelicans (Pelecanus philippensis), three species of cormorants (Microcarbo niger, Phalacrocorax fuscicollis, Phalacrocorax carbo) and four species of egrets (Egretta garzetta, Ardea alba, Egretta intermedia, Bubulcus ibis). Adjutants avoided deeper water, and seemed to prefer the muddy edges of the water hole. Individuals kept a fair distance from one other; were busy walking, probing, and prodding their bills into water. On two individuals, mud stains could be seen all over the bill, head, and neck. Unlike when they are solitary, the birds were not as shy, and could be approached to about $20 \mathrm{~m}$.

Out of the 103 people subjected to the questionnaire, only 56 recognized the species correctly (Table 2 ). As a common mistake people misidentified Painted Stork (Mycteria leucocephala) as Lesser Adjutant (17 out of 103 times). Senior citizens (age $>50$ years) knew the bird better (identification success $=68.8 \%$ ) than the younger generations (identification success $=43.1 \%$ ). According to the survey, the bird approached human habitations.

Evidences on nesting Lesser Adjutants were obtained 


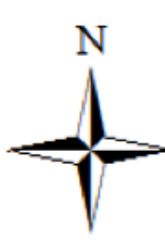

Observations in each year

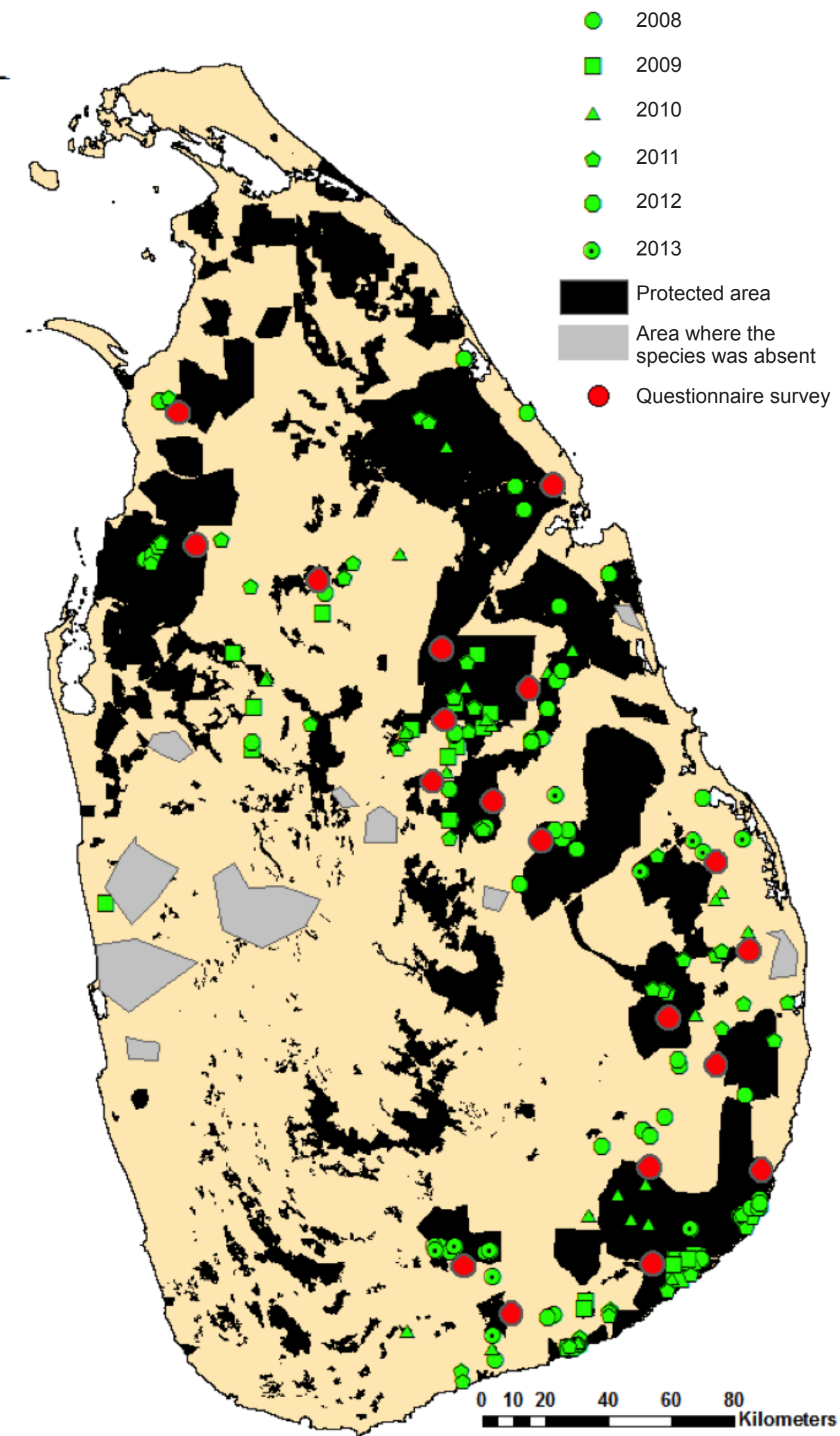

Figure 1. Distribution of Lesser Adjutant in Sri Lanka. 


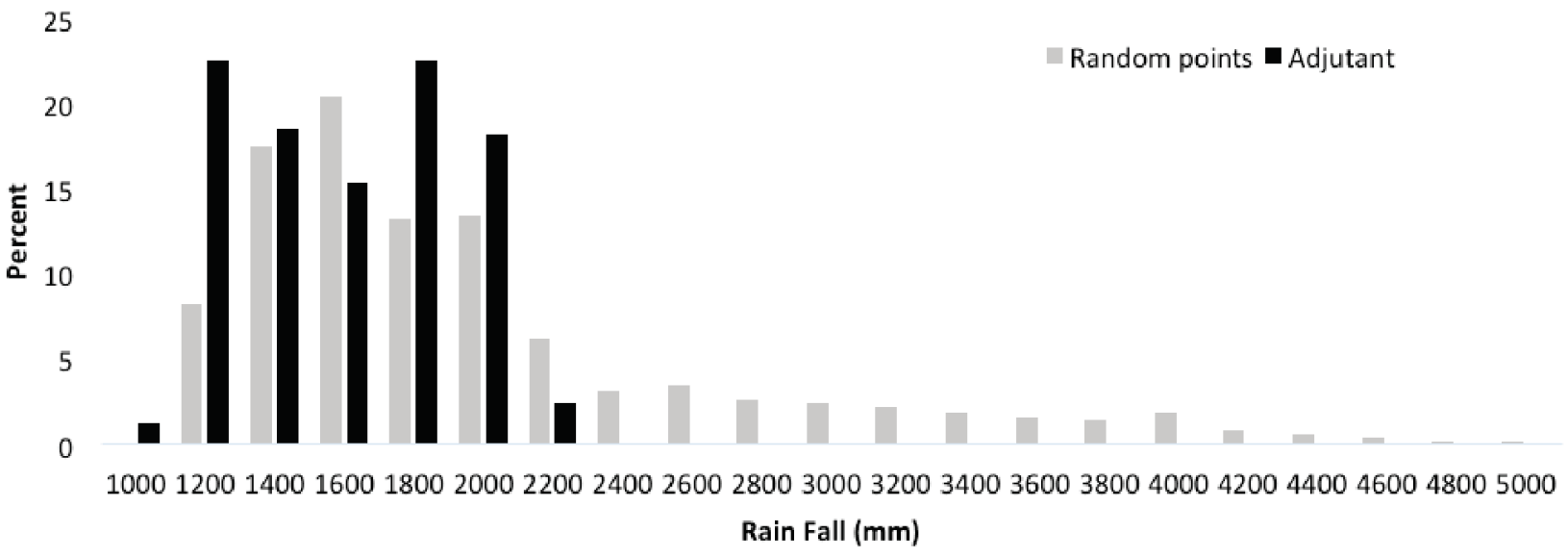

Figure 2. Percentage presence of Lesser Adjutant versus annual rainfall, with random distribution values (D) for comparison.

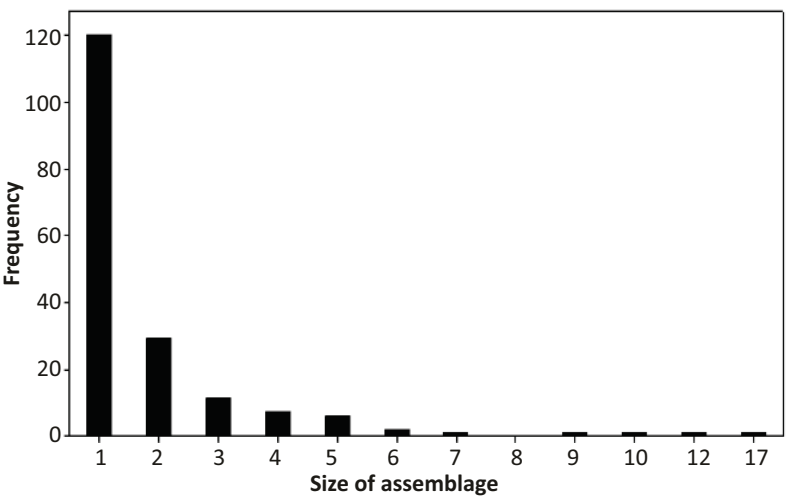

Figure 3. Frequency distribution of the numbers of individuals of Lesser Adjutant per sighting during the period of study

during the questionnaire survey from park rangers (Uda Walawe National Park and Maduru Oya National Park) and fishermen (Kuchchaveli), but no active nests were reported, other than a pile of sticks of what was apparently an abandoned nest on a Kolon (Adina cordifolia) tree in the thick jungle of Kuchchaveli, which the local fishermen claimed was that of the Lesser Adjutant, close to four ancient tanks long deserted by people. The nest was set up 20m from the ground, with a diameter of 1.4-1.7 $\mathrm{m}$. The shape was distorted and supposedly the bird bred there six years ago during the dry season (August-September). The nest obviously resembled that of a stork, but no confirmation was made. The site was approximately $1 \mathrm{~km}$ from the eastern coast.

The questionnaire survey further revealed several potential threats faced by the species, which varied across its local range. Habitat destruction by loss of mangrove forests to shrimp culture, agricultural intensification, hunting pressure, tourism, large-scale development projects, forest fragmentation, and illegal felling of trees were among major likely threats identified during the

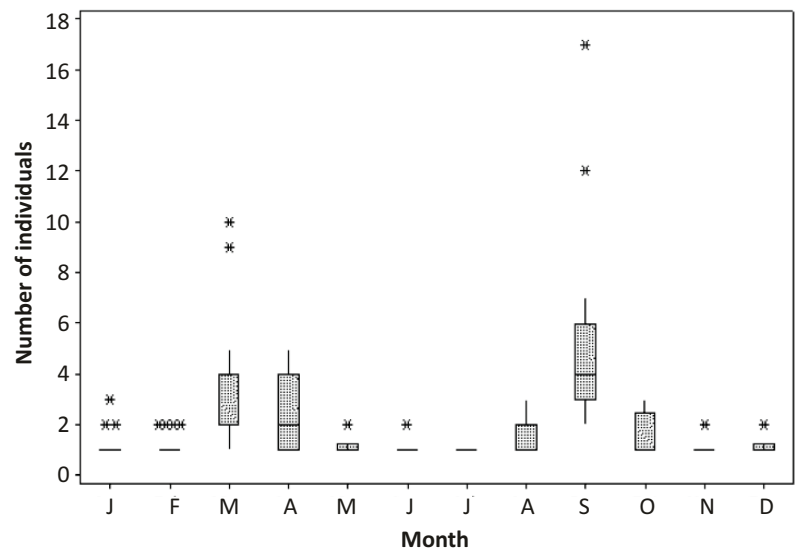

Figure 4. Variation in number of birds observed during each sighting during each month of the year.

study as listed by the locals.

\section{DISCUSSION AND CONCLUSIONS}

In Sri Lanka, the distribution of Lesser Adjutant appears to be determined by annual rainfall and elevation. Minimum temperature of the cold season is a major determinant of the distribution of this species according to Khadka \& Pandey (2013), which does not seem to be the case at least in Sri Lanka. Despite the slight temperature variation within the region, the bird's distribution aligns with the island's dry eco-regions, receiving an annual rainfall of 1,500-2,000 $\mathrm{mm}$ and with continuous dry evergreen forests (Attygalle et al. 2012), providing isolation and cover.

Coastal populations of Lesser Adjutants are known to favor coastal habitats, such as mangroves, mudflats, coastal swamps, estuaries, and salt marshes (del Hoyo et al. 1992). Even though Sri Lanka is an island with over 
Table 1. Habitat use of Lesser Adjutant

\begin{tabular}{|l|c|c|}
\hline Habitat & $\begin{array}{c}\text { Number of } \\
\text { observations }\end{array}$ & $\begin{array}{c}\text { Mean assemblage } \\
\text { size }\end{array}$ \\
\hline Savannah/woody savannah & 21 & 1.43 \\
\hline Permanent wetland & 11 & 3.09 \\
\hline Cropland/Paddy field & 7 & 1.14 \\
\hline Dry mixed evergreen forest & 16 & 1.31 \\
\hline
\end{tabular}

Table 2. Results of the questionnaire survey of local residents across Sri Lanka.

\begin{tabular}{|l|c|c|c|c|}
\hline & $\begin{array}{c}\text { Number } \\
\text { interviewed }\end{array}$ & $\begin{array}{c}\text { Identified } \\
\text { the species }\end{array}$ & $\begin{array}{c}\text { Identified } \\
\text { threats } \\
\text { faced }\end{array}$ & $\begin{array}{c}\text { Information } \\
\text { about } \\
\text { nesting }\end{array}$ \\
\hline Fishermen & 31 & 21 & Yes & Little \\
\hline Farmers & 24 & 8 & Yes & None \\
\hline $\begin{array}{l}\text { Park } \\
\text { rangers }\end{array}$ & 17 & 17 & Yes & Little \\
\hline Hunters & 2 & 2 & Yes & None \\
\hline $\begin{array}{l}\text { School } \\
\text { children }\end{array}$ & 22 & 4 & No & None \\
\hline Soldiers & 7 & 4 & Yes & None \\
\hline
\end{tabular}

$1300 \mathrm{~km}$ of coastline and an array of coastal habitats, the species appears to prefer inland waters. The possible reasons could be that undisturbed coastal habitats are rare, and the bird has never had close links with civilization (del Hoyo et al. 1992). The ancient tank cascade system, with its hundreds of small-to-mediumsized reservoirs in the lowlands of Sri Lanka is a crucial feature of the country's topography. These ancient tanks together with the protected-areas network in the dry lowlands provide water resources that would not otherwise exist (Geekiyanage \& Pushpakumara 2013). The Lesser Adjutant is one of many threatened species that appears to benefit; the bird is seldom observed outside of protected areas.

Despite five years of fieldwork, no active adjutant nest was discovered. Local residents who deal day to day with key areas, also had little idea as to where the bird breeds. Henry (1955) stated that, on several occasions, young birds had been brought alive to the Colombo Museum, but nests were rarely found. A possible guess about the bird's breeding season in Sri Lanka could be late August through September, the driest period of the year in the low country dry zone. The bird assembles in small groups during this time of the year, feeding actively in the drying pools, unlike its regular behavior. Individuals were observed swallowing medium-to-large-sized fish (Tilapia) whole, before flying off into the jungle. A possibility is that these individuals were feeding nestlings. Similar behavior was exhibited by the species in March and April,

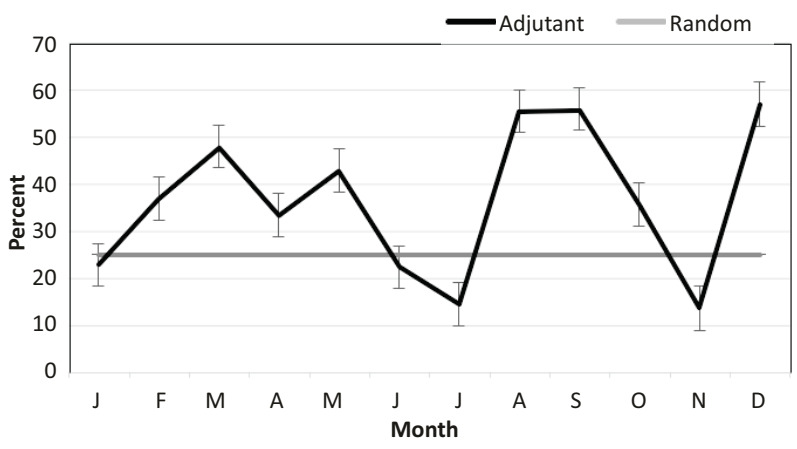

Figure 5. Percentage presence of Lesser Adjutant within protected areas in each month of the year, with random distribution values (D) for comparison.

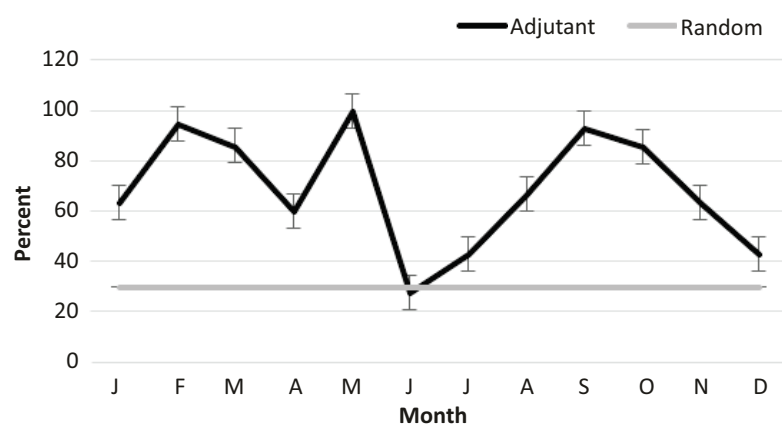

Figure 6. Percentage presence of Lesser Adjutant within the $1 \mathrm{~km}$ water buffer zone in each month of the year, with random distribution values (D) for comparison

suggesting a second possible breeding season. Both predicted breeding seasons of the bird match that given by the prominent British naturalist W.W.A. Phillips, from his extensive work on Sri Lankan avifauna in the early $20^{\text {th }}$ century (Henry 1955), while in other regions of the world the breeding season often extends between October and March (Chowdhury \& Sourav 2012; Mondal et al. 2013), with certain exceptions (Mondal et al. 2013).

The bird is locally known by various Sinhalese names such as 'Thatta-koka' (Sinhalese: Bald Stork), 'Mana-koka' (Sinhalese: Stork), 'Maa-koka' (Sinhalese: Great Stork) by villagers, as well as 'Thatta-manaava' (Sinhalese: Bald Stork) (Henry 1998), 'Bahuru-maanava' (Sinhalese: Adjutant Stork) (Kotagama \& Fernando 1994) and 'Heen bahuru-maanava' (Sinhalese: Lesser Adjutant Stork) (MOE 2012). According to paddy farmers, the species used to visit the paddy fields more frequently to feast on freshwater crabs 20-30 years ago, but would fly off at any suspicion of human presence. Lower identification rates of the species within the younger generations (age<50) could be due to considerably low species turnover in human altered landscapes at present compared to the past. Future studies on this species based on secondary 
information from non-specialist observers should take into consideration the chances of the bird being misidentified as the Painted Stork Mycteria leucocephala and vice versa.

Lesser Adjutants, along with other storks, are considered paddy pests in some regions; they have the bad reputation of crushing young paddy plants as they stride. The stork does not appear to have lost its historical range, though its habitat is assumed to have shrunk in the recent past (IUCN 2006, Birdlife International 2013). Populations in Northwestern Province were likely affected by the loss of mangrove forests, with expansion of shrimp aquaculture there. Not only were vast tracts of mangrove forests cleared, but this step led to severe water pollution with antibiotics, pesticides, and water additives (IUCN 2006). Organochlorine residues from pesticides are known to cause eggshell thinning in storks and other birds with fish diets (Ohlendorf et al. 1978). In the Northcentral Province agricultural intensification, and the associated use of agro-chemicals could be suggested as plausible threats, with reference to results obtained from the questionnaire survey. In the Eastern Province, major threats faced were tourism, large-scale development projects, and hunting pressure, as identified by the local stakeholders. Populations in the Southern and Uva provinces seem healthier and relatively well protected. Felling of trees and forest fragmentation are further threats faced by all adjutant populations throughout the island. Interestingly, felling of nesting trees, egg poaching, and hunting chicks, threats that the species commonly faces throughout its global range (BirdLife International 2013), are less likely to be dangers to the Sri Lankan populations; as nobody seems to know where the bird nests. These threats faced by the species and its immediate habitat was founded upon observations and views of the locals (park rangers, park wardens, hunters, etc.), based on their knowledge on the bird and its habitat. Emphasis was given to their comments considering the important role local stakeholders play in sustainable conservation strategies. Further research with better equipment, and thorough background knowledge on aspects such as water quality of associated habitats should be carried out to test the basis of these observations. Future studies should also focus on population status and nesting ecology of the species, in Sri Lanka, and conservation efforts should be highly encouraged.

\section{REFERENCES}

Attygalle, P., K.B. Ranawana \& T.N. de Silva (2012). Biodiversity and conservation importance of Manewakanda and Danduwellawa isolated hills in Kala Oya basin, Sri Lanka. http://journals.sjp.ac.lk/ index.php/fesympo/article/view/657. Electronic version accessed 24 July 2014.

BirdLife International (2013). Leptoptilos javanicus. The IUCN Red List of Threatened Species 2013. http://www.iucnredlist.org/ details/22697713/0 Electronic version accessed September 2015.

Chowdhury, S.U. \& M.D.S.H. Sourav (2012). Discovery of a Lesser Adjutant Leptoptilos javanicus breeding colony in Bangladesh. BirdingASIA 17: 57-59.

del Hoyo, J., A. Elliott \& J. Sargatal (1992). Handbook of The Birds of The World. Vol.1. Lynx Edicions, Barcelona, 440-464pp.

DIVA-GIS (2014). Free spatial data for Sri Lanka. http://www.diva-gis. org/Data. Downloaded on 13 June 2014.

ESRI (2011). ArcGIS Desktop: Release 10. Redlands, CA: Environmental Systems Research Institute.

Geekiyanage, N. \& D.K.N.G. Pushpakumara (2013). Ecology of ancient Tank Cascade Systems in island Sri Lanka. Journal of Marine and Island Cultures 2: 93-101.

Harrison, J. \& T. Worfolk (1999). A Field Guide to the Birds of Sri Lanka. Oxford University Press, Oxford, 35-37pp.

Henry, G.M. (eds.) (1998). A Guide to the Birds of Sri Lanka, 3rdedition. K.V.G. de Silva \& Sons, Kandy, 51-52pp.

Henry, G.M. (1955). A Guide to the Birds of Ceylon. Oxford University Press, London, 45pp.

IUCN (2006). Information Brief on Mangroves in Sri Lanka. http:// cmsdata.iucn.org/downloads/sri_lanka_information_brief_of_ mangroves.pdf. Downloaded on 27 July 2014.

Khadka, K.K. \& R. Pandey (2013). Changes in the distribution of Lesser Adjutant storks Leptoptilos javanicus in South and Southeast Asia: A plausible evidence of global climate and land-use change effect? International Journal of Zoological Research 10(1): 9-14.

Kotagama, S. \& P. Fernando (1994). A Field Guide to the Birds of Sri Lanka. Wildlife Heritage Trust, Colombo, 40pp.

MOE (2012). The National Red List 2012 of Sri Lanka; Conservation Status of the Fauna and Flora. Ministry of Environment, Colombo, Sri Lanka, viii+476pp.

Mondal, R.P., T.K. Dutta \& B. Dhua (2013). Reporting a new site record of the breeding population of Lesser Adjutant (Leptoptilos javanicus) from Bankura District, West Bengal, India. International Journal of Current Research 6: 4441-4443.

Ohlendorf, H.M., E.E. Klaas \& T.E. Kaiser (1978). Organochlorine residues and eggshell thinning in Wood Storks and Anhingas. Wilson Bulletin 90: 608-618.

Subaraj, R. \& A.F.S.L. Lok (2009). Status of the Lesser Adjutant stork (Leptoptilos javanicus) in Singapore. Nature in Singapore 2: 107-113.

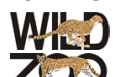

Author details: THILINA N. DE SILVA is PhD student of the Biodiversity Institute at the University of Kansas USA, studying ecology and evolution of weaverbirds (Family: Ploceidae). Completed bachelors at the University of Peradeniya with honors in Zoology. SUMUDU FERNANDO is PhD student of the Biodiversity Institute at the University of Kansas studying evolution, distribution patterns and speciation of Treepies and Blue-magpies. Completed bachelors at the University of Peradeniya Sri Lanka with first class honors in Zoology. HARITHA B. DE SILVA is undergraduate of University of Peradeniya. Research assistant entomological laboratory of Department of Zoology. Secretary of 'Defenders of Wildlife Sri Lanka', an organization for wildlife conservation. PARAMI TeNNAKOon is Assistant Divisional Secretary at the Dimbulagala Divisional Secretariat. Obtained his bachelors degree from the University of Peradeniya with honors in Zoology. A wildlife enthusiast and a popular civil servant. Involved in community services in Dimbulagala.

Author Contribution: Author 1 - Designed the project to fill the gaps in knowledge about Lesser Adjutant in Sri Lanka. Took part in field studies and surveys. Prepared the manuscript with the help of authors $2 \& 3$. Author 2 - was the main person behind the literature survey. Contributed to field observations and questionnaire surveys. Prepared the manuscript and figures with authors 1 \& 3. Author 3 - Main person behind fieldwork and observations. Contributed to the manuscript and developed the figures with author 2. Author 4 - Handled the human component of the study. Facilitated the questionnaire survey. Was actively involved in interviewing local communities. Contributed a lot toward achieving hard goals in the field. 